M.

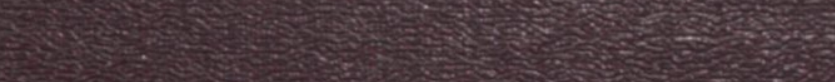

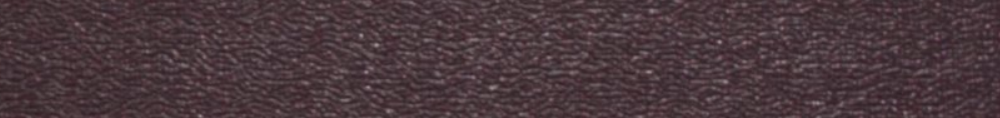

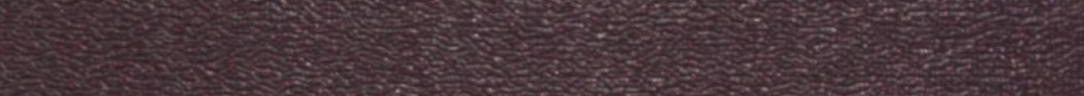

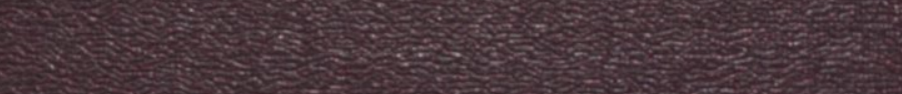

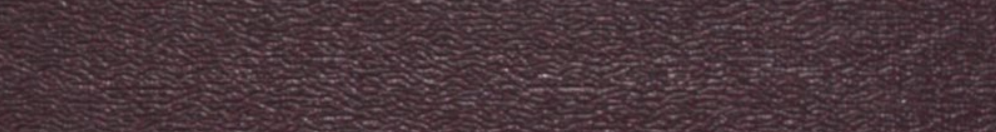

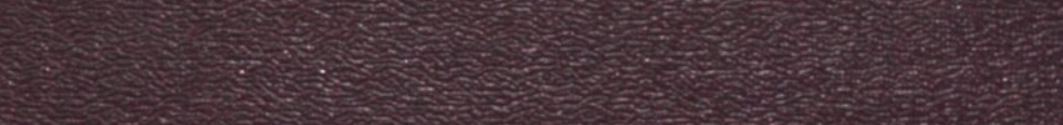

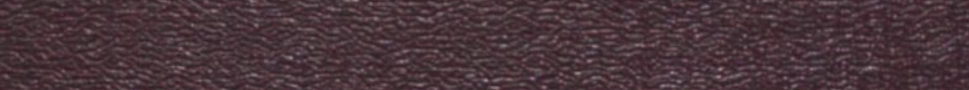
(1) (1) S.5.5. 
BIJDRAGEN TOT DE TAAL-, LAND- EN VOLKENKUNDE VAN NEDERL.-INDIË 


\title{
BIJDRAGEN TOT DE TAAL-, LAND- EN VOLKENKUNDE VAN NEDERLANDSCH-INDIË
}

\author{
UITGEGEVEN DOOR HET \\ KONINKLIJK INSTITUUT VOOR DE TAAL-, \\ LAND- EN VOLKENKUNDE VAN \\ NEDERLANDSCH-INDIË
}

DEEL 95

's-GRAVENHAGE - MARTINUS NIJHOFF - 1937 


\section{INHOUD.}

Bladz.

Bijdrage tot de kennis der Javaansche werkwoordsvormen. (Met 4 bijlagen). Door C. C. Berg . . . . . . . . . . . 1

Oudheidkundige aanteekeningen. (Met 2 illustraties). Door Dr. W. F. Stutterheim . . . . . . . . . . . . . 397

Het begrip „Marapoe” in den godsdienst van Oost Soemba. Door Ds. P. J. Lambooy . . . . . . . . . . . . 425

Twee koperen oorkonden van Balitung in het Koloniaal Instituut te Amsterdam. Door F. H. van Naerssen . . . . . . . 441

Notulen van de Bestuursvergaderingen en Algemeene Vergadering.

Bestuursvergadering van 19 September 1936 . . . . . In

Bestuursvergadering van 17 October 1936 . . . . . . VI

Bestuursvergadering van 21 November 1936 . . . . . IX

Bestuursvergadering van 19 December 1936 . . . . . xI

Bestuursvergadering van 16 Januari 1937 . . . . . . XIV

Bestuursvergadering van 20 Februari 1937 . . . . . XvIII

Algemeene Vergadering van 20 Maart 1937 . . . . . xxiiI

Jaarverslag over 1936 . . . . . . . . . . . . . XxIV

Bestuursvergadering van 20 Maart 1937 . . . . . . . xxviII

Bestuursvergadering van 17 April 1937 . . . . . . . xxx

Bestuursvergadering van 15 Mei 1937.. . . . . . xxxIII

Bestuursvergadering van 19 Juni 1937 . . . . . . . xxxv 